\title{
THE PRIMA FACIE CASE IN NON-JURY TRIALS
}

\author{
ROSCOE STEFFEN†
}

1

1 HE MU-POINT in a law suit has always, and quite rightly, been a time of testing. The plaintiff has presented his evidence, or so much as counsel has thought necessary, and the question is whether a sufficient showing has been made to require the defendant to go on with his case. Or, to put the question in the usual way, has plaintiff made out a prima facie case? The issue is raised in jury cases by a defense motion for a directed verdict; ${ }^{1}$ in nonjury cases, by several devices, as by a motion for non-suit ${ }^{2}$ or, in Federal practice today, by a motion to dismiss "on the ground that upon the facts and the law the plaintiff has shown no right to relief."3 So much is clear enough, or would seem to be. But what is not so clear is whether, in a non-jury case, the trial judge should evaluate the plaintiff's evidence just as he would if the case were being tried to a jury.

It may be that the idea of a prima facie case has no place in the non-jury trial. The judge, there, is himself the trier of fact and, hence, or so the argument runs, may as well proceed at once to "weigh" the plaintiff's evidence. ${ }^{4}$ If it is

$\dagger$ John P. Wilson Professor of Law, University of Chicago Law School. The writer is happy to acknowledge much help from talks with colleagues, and from student papers, especially papers by Richard B. Berryman, John V. Gilhooly, Phillip Mullock and Stephen K. Waite.

${ }^{1}$ See, Hackett, Has a Trial Judge of a United States Cont the Right to Direct a Verdict, 24 YALE L.J. 127 (1914). As to the old practice of demurring to the evidence, see TrayER, PREinmary Treatise on Evidence at the Comaron Law 234 et seq. (1898). The procedure was extensively re-examined by both the majority and minority in Galloway v. United States, 319 U.S. 372 (1942).

2 See, Slocum v. New York Life Ins. Co. 228 U.S. 364,394 (1912), a case dealing with the power of a court to give judgment notwithstanding a jury verdict, where Mr. Justice Van Devanter comments: "In what has been said we would not be understood as implying that a motion for a compulsory nonsuit and a demurrer to the evidence are equivalents of a request for a directed verdict, for while they are sometimes spoken of as analogous to it, this only means that for the purpose of each the evidence must be taken most strongly in favor of the opposite party."

${ }^{3}$ FED. R. Crv. P. 41(b).

${ }^{1}$ The argument appears to have been first stated, and most fully, by Hoyt, C.J. in Lambuth v. Stetson \& Post Mill Co., 14 Wash. 187, 190, 44 Pac. 148, 149 (1896). There, in sustaining a dismissal by the trial court at the end of plaintiff's case, Judge Hoyt said: "When the trial is before a jury, the court cannot weigh the testimony upon a motion for a nonsuit, for the reason that it cannot weigh it at any time; but, when the trial is without a jury, the court must eventually weigh the testimony for the purpose of determining where the preponderance is, and there is no reason why it should not so weigh it at the earliest possible time, when the rights of the plaintiff will not be cut off by its so doing; and when the plaintiff has introduced all of his proof and rested, no right of his will be cut off if the court then determines what has been proven. It cannot be presumed that plaintiff's case will be strengthened by the evidence put in by the defendant." 
found wanting, why should he not then make findings of fact and conclusions of law, in the usual way, and forthwith direct that judgment be entered for defendant? Not only would that seem to be the expeditious way to do, but it is said to be "just," for the plaintiff has had his day in court, and it cannot be supposed that his cause would be helped, were the court to hear the defendant's evidence. ${ }^{5}$ Moreover, even if the contrary were true, plaintiff has no vested right to require defendant to put on his case. ${ }^{6}$ These were the arguments, sanctioned in several Circuit Court cases to be noticed later, which brought about the 1946 amendment to Rule 41(b) of the Federal Rules. ${ }^{7}$ It is now made discretionary with a trial court, when sitting without a jury, either to deny the motion, presumably upon the ground that a prima facie case exists, or to weigh the evidence and dispose of the case at once.

Thus, the rule-makers chose to straddle the issue, and let the trial courts do as they might think best. This, at least, was an easy solution-and not displeasing to the trial courts-though plainly it meant that any trial judge might, at will, over-turn a practice of very long standing under which the rights of plaintiff and defendant to a full hearing on the merits had been kept in fairly even balance. Traditionally, courts have felt impelled to withhold judgment, in non-jury as in jury cases, when a plaintiff has introduced "substantial" evidence upon which a reasonable person might find in his favor. ${ }^{8}$ Perhaps there is in this a certain wisdom born of long experience, for even plain cases sometimes take on a different aspect when both sides are heard. ${ }^{9}$ However that may be, the

${ }^{5}$ Porter v. Wilson, 39 Okla. 500, 135 Pac. 732 (1913). Plaintifi's claim here hinged on whether his mother and father had been married according to the customs of the Creek Indians. It was urged that defendant's demurrer to the evidence admitted the facts tending to make out plaintiff's case and that, if they supported the necessary allegations of the complaint, the demurrer should be over-ruled. But the court held to the contrary; the trial judge, sitting without a jury, was said to have acted properly in "weighing the plaintiff's testimony for the purpose of determining the rights of therespective parties." Id. at 503. It is not clear whether the trial judge thereby determined (1) that no reasonable person might find for the plaintiff on the evidence when so "weighed," or (2) that the trial judge himself was not persuaded, whatever other reasonable men might think. The point, if apprehended, was not considered material, for the court said, "there being testimony reasonably tending to support the judgment of the court, the same will not be weighed by this court to ascertain whether the court's decision is against the preponderance of the testimony." Id. at 508.

${ }^{6}$ Porter v. Wilson, 239 U.S. 170 (1915), is usually cited for this point. See Note, $45 \mathrm{MICH}$. L. Rev. 788 (1947). Needless to say, Mr. Justice McKenna did not make so broad a statement; the holding was that plaintiff's rights under the Fourteenth Amendment had not been shown to have been violated by the action of the Oklahoma court.

7 The third sentence of Rule 41(b) now reads: "In an action tried by the court without a jury the court as trier of the facts may then determine them and render judgment against the plaintiff or may decline to render any judgment until the close of all the evidence."

${ }^{8}$ See: Maryland Casualty Co. v. Jones, 279 U.S. 792 (1929); Jefferson Electric Mfg. Co. v. United States, 291 U.S. 386 (1934); Gunning v. Cooley, 281 U.S. 90 (1930).

' See comment of Justice Van Orsdell in Catholic University of America v. Waggaman, 32 App. D.C. 307, 320 (1909): "While we recognize the rule that it is incumbent upon the plaintiff to establish a prima facie case by affirmative evidence before the defendant can be put upon 
amended rule encouraged, if it did not require, trial judges to reach a decision at once. And the result, it would seem, has been increasingly to dismiss without hearing the other side; but that this should be so is perhaps the purpose of the new procedure.

Such in brief are the arguments for change. But surely so venerable an institution as the prima facie case in non-jury trials is not to be dispatched that summarily. At most the proponents of the new procedure have made a prima facie case; and, under the traditional practice, the other side is entitled to be heard. At all events, it is proposed in what follows to look first in more detail at how and why the new rule came about, and then to examine into some of its implications, which, if considered, do not appear to have been given sufficient weight by the rule-makers. In other words, it is proposed to see what sort of a case can be made for the prima facie rule. ${ }^{10}$

\section{Construction OF RULe 41(b)}

The first court to construe Rule 41(b), prior to the 1946 amendment, had little doubt as to its meaning. The case, Federal Deposit Ins. Corp. v. Mason, ${ }^{11}$ was brought to recover the amount of certain dividends alleged to have been unlawfully declared and paid out by the defendants. After reviewing plaintiff's evidence, Judge Maris held that the lower court had erred in dismissing the case: "Inasmuch as an order of dismissal under Rule 41(b) is the equivalent of a directed verdict we must upon review of such an order view the evidence and all inferences reasonably to be drawn therefrom in the light most favorable to the plaintiff." 12 And, in that light, plaintiff was said to have made out a case sufficient to go to a jury, hence, sufficient to require the trial court, sitting without a jury, to hear defendant's evidence before reaching a decision.

There seems to be little doubt that the rule-makers regarded the motion to dismiss and the motion for a directed verdict to be controlled by the same procedure. Indeed, the Advisory Committee, in its note to Rule 41(b), said that "it provides the equivalent of the directed verdict practice for jury actions which is regulated by Rule 50.'13 And, at the New York Symposium, when asked whether a court must make findings of fact, either upon granting a motion for dismissal or for a directed verdict, Mr. William D. Mitchell was

his proof, yet, where the plaintiff has established a state of facts from which the jury can draw reasonable inferences tending to sustain the contention of the plaintiff, it is error for the court to dispense with the services of the jury. Especially is this true where the evidence of the defendant must, of necessity, be such as to illuminate the issues and assist the jury in arriving at a proper and just verdict." But then, things moved at a slower pace in 1909.

${ }^{10}$ The writer's initial bias in this matter came when he argued and lost the point in United States v. United States Gypsum Co., 67 F. Supp. 397, 417 (D.D.C. 1946).

${ }^{11} 115$ F.2d 548 (3d Cir. 1940).

12 Id. at 551.

1328 U.S.C.A. 204 (1958). 
quite explicit: "The answer is 'No'. Rule 52 with regard to findings is based on the assumption that you will pay a little regard to the practice in the courts for the last 150 years." $14 \mathrm{Mr}$. Mitchell went on to say that a case dismissed upon motion was not one "tried upon the facts," 15 and so, literally speaking, would not come within Rule 52. No one supposed, it seems, that a trial court would ever attempt to "weigh" plaintiff's evidence, when passing on such a motion.

But in Gary Theatre Co. v. Columbia Pictures Corp..${ }^{16}$ an anti-trust case, the trial court, sitting without a jury, purported to have done that very thing. That is to say, at the end of plaintiff's case the court proceeded to weigh the evidence and make findings of fact and conclusions of law. Moreover, Judge Lindley, on appeal, saw nothing strange in this. Without regard to prior practice; without reference to the probable purpose of the rule-makers; he refused to consider, as he was urged to do, whether plaintiff had made out a prima facie case: "Under Rule 41(b) the judgment, supported by findings, was an adjudication upon the merits, inasmuch as defendants moved for dismissal upon the ground that, upon the facts and the law, plaintiff had shown no right to relief."17 Hence it followed that, under Rule 52(a), the judgment could not be reversed, unless the trial court's findings of fact could be set aside as "clearly erroneous." And that, "we do not believe we are justified in doing."18

The case of Young v. United States, ${ }^{19}$ decided a year earlier in the Ninth Circuit, is usually cited as supporting the same conclusion. But, there, the defendant had rested his case at the end of plaintiff's evidence. In such circumstance, obviously, the lower court's judgment and findings of fact were upon the whole case; the time to inquire whether plaintiff had made out a prima facie case had passed. Nonetheless, Judge Wilbur appears to have reasoned the case as one calling for a construction of Rules $41(\mathrm{~b})$ and $52(\mathrm{a})$. "These rules," he said, "do away with the former distinction," in California practice, "between a judgment of nonsuit and a judgment on the merits in all suits or actions where the court sits without a jury." 20 It followed that the case could be reversed only if the trial court's findings were "clearly erroneous." The lower court was affirmed.

These cases, it will be noted, did not pass on the question as a matter of policy; they merely held that a trial court had power to weigh plaintiff's evi(1938).

${ }^{15}$ Ibid.

${ }^{16} 120$ F.2d 891 (7th Cir. 1941).

${ }^{17} I d$. at 892 . The court may have been confused by the thought that, because the dismissal was "on the merits," findings were required. Rule 41(b) provides, however, that any dismissal (except for lack of jurisdiction or improper venue) "operates as an adjudication upon the merits."

${ }^{18} \mathrm{Id}$. at $894-95$.

${ }^{19} 111$ F.2d 823 (9th Cir. 1940). $\quad{ }^{20}$ Id. at 825. 
dence and make findings of fact when ruling on a motion to dismiss. But in Bach v. Friden Calculating Mach. Co. ${ }^{21}$ a Sixth Circuit case decided in 1945, Judge Hamilton went further. Asserting, first, that "the purpose" of the rules, as if there were only one, "is to expedite the trial of cases," he went on to say that the question was one of "fact," and that the "sensible course" for a trial court is to dismiss if plaintiff has not made out his case "by a preponderance of evidence." 22 Nor would appellants be hurt if that were done;

they have advanced their whole cause by putting in all of their evidence and it would be $a$ refinement of technicality to say that such evidence and all reasonable inferences to be drawn therefrom must be viewed in the light most favorable to the appellants and if there be any substantial evidence supporting their claim, the court must put the appellees to proof. ${ }^{23}$

Again, the lower court was affirmed.

Then in 1946, Judge Stephens, sitting as a trial judge in United States $v$. United States Gypsum Co. ${ }^{24}$ put the matter even more strongly. Not only would it be proper for a trial court to weigh plaintiff's evidence under Rule 41(b), but, he said, "it is the duty of the court to weigh the evidence, to draw inferences therefrom and, if it finds the evidence insufficient to make out a case for the plaintiff, to render a decision for the defendant on the merits." ${ }^{35}$ Moreover, Judge Stephens thought the weighing should be done with care; he took more than two years in which to do the job, wrote a scholarly 120 page opinion, made some 118 detailed findings of fact, and stated a dozen conclusions of law. ${ }^{26} \mathrm{It}$ is not clear whether the rule-makers relied on this decision also, when amending Rule 41(b), but it gave unqualified support for their action. Once again, the plaintiff's case was dismissed.

Thus, when the question reached the rules committee, the clear "weight of authority," at least, favored a construction which permitted a trial court to weigh the plaintiff's evidence. And, likewise, to make findings of fact and conclusions of law. The amendment to Rule 41 (b) made it clear that this was a proper procedure. But it also provided quite as clearly that a trial court, if it thought best, might "decline to render any judgment until the close of all the evidence." ${ }^{27}$ That is, if a trial court should determine that there was substantial evidence in the record upon which a reasonable person might decide for the

21148 F.2d 407 (6th Cir. 1945).

${ }^{22} I d$. at $410-11$.

${ }^{25} I d$. at 419-420. (Emphasis added.) Judge Stephens noticed the point that the rule-makers had said the motion to dismiss was the equivalent of a motion for a directed verdict, but, he said, this was true only in the sense that, in each case, if the motion was denied the defendant might proceed to put in his case. It was therefore said to have no bearing on the issue before the court. Any other construction, he said, would "ignore" the fact that in non-jury cases the judge, himself, is the "trier of the facts."

${ }^{26}$ This experience alone would suggest that not much court time is saved by the "weighing" procedure.

${ }^{27}$ FED. R. Crv. P. 41(b). 
plaintiff-whether or not the court had reached that decision for itself-the defendant's motion to dismiss could properly be denied.

Nothing was said, at least not directly, upon whether a trial court (without weighing the evidence) might still dismiss for the reason that plaintiff had failed to make out a prima facie case. That procedure was simply given a cold shoulder, possibly to encourage trial courts increasingly to make findings of fact, and so to facilitate appellate review. But it must be remembered that the motion to dismiss under Rule 41(b) proceeds on a dual ground, that is, "upon the facts and the law." Thus, clearly, a trial court may properly dismiss a case solely as a matter of law, ${ }^{28}$ and a disposition on that ground operates "as an adjudication upon the merits" within the rule, quite as much as if the court had dismissed the case as a "trier of the facts," after weighing the evidence. Therefore, since the question - whether plaintiff has made out a prima facie casehas always been held to be one of "law," court may still properly grant a motion to dismiss on that basis, without making findings of fact. The case then is not in any real sense "tried" on the facts.

\section{Experdirental TrIal Data}

It has been blandly assumed up to this point, as is customary with lawyers, that more cases would be dismissed under the "weighing" test, than under the "substantial" evidence rule. Indeed, the proponents of the "weighing" test regard this not only as fact, but as a virtue. Perhaps they are wrong on their basic assumption; certainly a person who has not experienced the stress and anxiety of presenting a closely contested case in court may well regard the whole thing as a matter of words, and say that no significant difference would occur. Who knows how judges actually dispose of cases, they ask, whatever formula is used? This is a healthy attitude, I suppose, but it leads exactly nowhere.

At all events, in order to get some quantitative idea of what, if any, difference might be expected, the following experiment was set up. ${ }^{30}$ The sound track of a mock presentation of an actual negligence case, replete with question, answer,

${ }^{28}$ For example, plaintiff may have failed to state a cause of action. Or, as in Oscanyan v. Arms Co., 103 U.S. 261 (1880), plaintiff may have disclosed in his opening statement that he had no lawful right to recover. Findings in such cases would be superfluous, if not impossible.

${ }^{29}$ See MIaryland Casualty Co. v. Jones, 279 U.S. 792, 795 (1929), a jury-waived case, where MIr. Justice Sanford said: "The motion for nonsuit-which corresponded to a motion for a directed verdict-presented the question whether the evidence, with every inference of fact that might be drawn from it in favor of the plaintiff, was sufficient in matter of law to sustain a judgment. See Central Transp. Co. v. Pullman's Car Co., 139 U.S. 24, 38. This presented a question of law which is reviewable...."

${ }^{30} \mathrm{~A}$ team of lawyers and social scientists at the University of Chicago Law School is currently engaged in a major study of the American jury system, under a grant from the Ford Foundation. One principal technique of investigation has been the experimental jury. With the cooperation of the courts in several cities, recorded mock trials- based on the transcripts of actual cases-have been submitted to juries drawn from the regular jury panel and have been decided by them in the atmosphere of the courtroom. It has thus been possible to utilize the regular adult jury population, to try the same case repeatedly, to test experimental varia- 
objection and ruling, arguments of counsel, the trial court's instruction, and so on, was played to a college class of 48 . Each member of the class, acting individually, was asked to reach a decision upon the merits at the end of the case. But, midway, a motion to dismiss was made, and each member was instructed to pass upon it in the role of a trial judge. The instructions to 30 members of the class were to determine, individually, whether there was substantial evidence so far presented upon which a reasonable person might decide in favor of the plaintiff. The members of the other group, 18 in number, ${ }^{31}$ were separately instructed to go a step further, that is, to weigh the evidence in accordance with the court's instructions and to decide, each for himself, whether plaintiff in fact had sustained the burden of proof and made out a case on the merits.

It is not suggested, of course, that such an experiment necessarily "proved" much of anything. For, however careful the experimenter may be to follow actual court procedure, it still is true that one is an experimental trial, the other an actual one. Nonetheless, the results did confirm the trial lawyer's hunch, that there is a very real difference between the two tests. Of the 30 students who used the "substantial" evidence test, 25 were for denying the motion to dismiss, while only 5 granted it. On the other hand, of the 18 who were instructed to "weigh" the evidence, 10 were for denial, while 8 granted the motion. For the benefit of the lay reader, the ratio in the first case, thus, was 1 to 5 for dismissal, in the second, 4 to 5 . That would seem to be quite a variance. ${ }^{32}$ Stated percentage-wise, 17 per cent in the first group were for dismissing the action, and 44 per cent, in the second. For those readers who gauge the soundness of their judgment by the conventions of statistical inference, the difference, of 27 per cent, is significant at the .05 level. ${ }^{33}$

tions, and to record in full the deliberations of the jury on the experimental case. The experimental jury work has been conducted by Professor Fred L. Strodtbeck of the Social Psychology and Sociology faculties of the University of Chicago in collaboration with Professor Harry Kalven, Jr., of the Law faculty.

The experiment described in the text was administrated by Professor Strodtbeck and represents an adaptation of one of the experimental scripțs-the so-called Conway case, dealing with the possible liability of a manufacturer and a retailer for injuries caused by a defective vaporizer. The experimental jury researches are now in the process of write-up for publication in book form. A full report on the Conway case will be included therein.

${ }^{31}$ The difference in numbers between the two groups was a matter of chance.

${ }^{32}$ Later the same experiment was tried with a law class which had had two quarters of schooling. The direction of the differences was the same as for the college class, but the extent was less, and not enough to be statistically significant. Perhaps this could be explained by the saying, a little law is a dangerous thing. But it might well be accounted for by one change in the format; the members of the law class did not receive their instructions, to "weigh" or not, until midway; the members of the college class, on the other hand, received their instructions at the start, and so, no doubt, were busily "weighing" or testing for "substantiality" as they listened to the evidence. This, of course, conformed more closely to trial practice, as it may be assumed the trial judge would know at the outset which rule he intended to apply.

${ }^{33} \mathrm{~A}$ significance level of .05 or .01 represents the risk that one takes that one's decision is wrong. The arithmetical operations for testing a statistical hypothesis of the type here used are described in all modern introductory statistics texts in connection with the chi-square dis- 
But does it follow that there would be any important difference in ultimate result? Perhaps the appellate machinery would return those cases, if any, which were improperly dismissed, so that, except for the delay and expense involved, plaintiff would not have been hurt. Before taking up this question, let us first see what happened when the dismissed cases were carried on to a conclusion. Of course, in actual practice, data of this sort is not available. But on an experimental basis it was a perfectly proper thing to ask each student to give his decision upon the whole case at the end, regardless of how he may have ruled on the motion to dismiss.

The results, here too, were interesting. Of the first group, that is, the one using the "substantial" evidence test, only 1 of the 5 who had voted to dismiss changed his mind and held for the plaintiff. But of the second group, 3 of the 8 who had dismissed after "weighing" the evidence changed their views, and voted for the plaintiff. ${ }^{34}$ That is, not only was a larger percentage of cases dismissed under the "weighing" test, but a larger percentage of the cases so dismissed were later decided for plaintiff, after all the evidence was in for both sides. But, the difference in result between the two tests was only 18 per cent, and, we are reminded, that is not quite a statistically significant difference. ${ }^{35}$

tribution, see for example, Drxon \& Massex, Introduction to Statisticat ANarysis, 18491 (1951). The line of inference is first to assume that the two sets of students have been drawn from a population in which the percentage who "deny" is the same as that of the two sets combined. Then, by reference to standard distributions, it is possible to determine how frequently a difference of the observed magnitude would have been expected to occur. This assumes repeated samples of the size here used from a very large population. If the difference in question would have occurred less than one time in twenty trials, then one rejects the null hypothesis that the samples were drawn from the same population. Proceeding on this basis, one assumes that the samples were from different populations which had different dispositions to "deny." This assumption is right 95 per cent of the time and wrong 5 per cent of the time. If the criterion for rejecting the null hypothesis were more stringent, thereby reducing the 5 per cent, one would increase the frequency of errors of a second type: namely, the error of saying that two samples were from the same population, when, in fact, they were from different populations. It should be clear that, useful as they are, significance tests, and other related statistical criteria do not go to the problem of generalizing from what students do to the behavior of judges. (Per, Prof. Strodtbeck.)

${ }^{34}$ We started with an hypothesis that, if a judge were to actually make up his mind to decide for the defendant-on the basis of plaintiff's evidence alone-it would be more difficult for him, should he be reversed on appeal, to hear the defendant's evidence fairly, than if he had merely examined plaintiff's evidence in the first place under the "substantial evidence" test. But this was not borne out, though not disproved either. See generally, FESTINGER, A Theory of Cognitive Dissonance (1957).

${ }^{35}$ Perhaps, though, it is legally significant. See Judge Frank, dissenting in United States v. Johnson, 238 F.2d 565, 571-572 (2d Cir. 1956), a case where the majority had denied a motion to appeal in forma pauperis: "The way out of this apparent dilemma is to consult the interest of justice: Surely, even if but one out of a hundred attempted appeals by indigents has merit, justice compels the conclusion that that appeal shall be heard. It is no answer that so many appeals will result as to 'crowd the docket.' If so, more judges should be appointed. True, the cost of running the government will somewhat increase. But I, for one, cannot sleep well if I think that, due to any judicial decisions in which I join, innocent destitute men may be behind bars solely because it will cost the government something to have their appeals considered." 
What, then, of appellate review? That is a matter to be examined later, in the light of the case law. But in the cases dismissed upon the "substantial" evidence rule, it may be assumed the appellate courts would use the same test in their deliberations. ${ }^{36} \mathrm{It}$ is the situation where the trial court has "weighed" plaintiff's evidence, and found that he failed to sustain the burden of proof, which gives concern. One's hunch, here, is that a much smaller number of reversals would occur. ${ }^{37}$ But perhaps that is as it should be; at any rate, that is the question.

It should be noted that this experiment dealt with a closely balanced case..$^{38}$ But it is in just such cases, it would seem, that the judicial machinery should be most carefully adjusted. In the fringe cases, where a plaintiff has either failed to put in any proof at all or, on the other hand, has presented over-whelming evidence, it should not make too much difference which rule is used by the trial court. But plainly it will not do to argue from such cases-as some proponents of the "weighing" rule appear to do-that, in every case, when a trial judge has made up his mind on the merits adversely to plaintiff, he should grant defendant's motion to dismiss the case and direct a judgment. Or, that the appellate machinery should be geared to sustain his judgment.

\section{A ReFineMENT OF TeCHNICALITY}

It would be well now to look more carefully at the role of the trial judge when sitting without a jury. The experimental data just discussed indicate that many more actions will be dismissed under the "weighing" test than has been true under the "substantial" evidence rule. And the data suggest, at least, that some of these will be dismissed unfairly. How, then, is one to explain the change? It surely is no answer to point out-with the air of a man who has just discovered fire for the first time-that in the non-jury case the judge himself is a trier of fact. It is not complimentary to prior courts to suggest that they really were not aware of their dual role when trying a case without a jury. Nor is it any more so to say that they probably were misled "by the unnoticed process of generalization";39 that is, since the "substantial" evidence rule was used when passing on a motion for a directed verdict, they just supposed the same rule must apply in all cases.

The best affirmative argument, it seems, is the presumed artificiality of

${ }^{36}$ Federal Deposit Ins. Corp. v. Mason, 115 F.2d 548 (3d Cir. 1940).

${ }^{37}$ It is one thing to test the trial court's action by asking whether there is any substantial evidence (which a jury or an appellate court might believe) to support a judgment for plaintiff, and a very different one to ask if there is substantial evidence to support the court's action in dismissing the case. One tends to hold judgment in abeyance until the evidence is all heard, the other to close the case out as soon as may be.

${ }^{38}$ Of the 50 juries who heard the case, in the course of the experimental jury study, 22 found for the plaintiff against the manufacturer alone, 1 against the distributor alone, and 10 against both defendants.

${ }^{39}$ Note, 45 Micr. L. Rev. 788,789 (1947). 
applying the "substantial" evidence test, ${ }^{40}$ in non-jury trials. The demand of Rule 1 for a "speedy" determination of every action is surely a subsidiary one. ${ }^{41}$ At all events, Judge Stephens puts the argument on artificiality as well as any one. "It is not reasonable," he said, "to require a judge, on motion to dismiss under Rule $41(\mathrm{~b})$, to determine merely whether there is a prima facie case," for that would compel "a defendant to put on his case and the court to spend the time and incur the public expense of hearing it ... even though the judge had concluded that on the whole of the plaintiff's evidence the plaintiff ought not to prevail." 42

So stated, the argument has a certain plausibility. There are, of course, many cases where a plaintiff may have wholly failed to establish his case, or an essential part of it, which comes to the same thing. Defendant's motion then should be quickly granted. But why would it not suffice to dismiss upon the the ground that plaintiff had failed to put in "substantial" evidence to support a judgment in his favor? In many cases, no doubt, it would. But in the closely balanced case, it seems, it would not. There the trial judge may be quite sure, in fact, that plaintiff has put in "substantial" evidence to support his case; that other reasonable men, to-wit: a jury or an appellate court, might well decide in his favor; but the trouble is that the judge himself has "concluded" that "plaintiff ought not to prevail." 43 Hence, he decides to "weigh" plaintiff's evidence.

This puts a somewhat different face on the matter. Perhaps the trial court holds strong views opposed to the policy of the existing law. Perhaps, the trial court's new-found interest in his role as a trier of fact is a move to give his determinations, half way through a case, that degree of finality which is accorded a jury verdict at the end. And, by so much, to make it the more difficult for an appellate court to reverse. This, of course, cannot be true, even though no trial judge likes to be reversed.

But, still, why are trial courts so anxious to "weigh" a plaintiff's evidence? There is no gainsaying the point that the weighing test is highly advantageous to a defendant. It gives him two bites at the apple, so to speak, where heretofore he has had but one. At the end of plaintiff's case he may say: " $I$ know that plaintiff has put in 'substantial' evidence, but perhaps on a 'weighing' the trial court will dismiss, in which case, at the very least, I will have gained one or two years delay. If the case is returned, I will go ahead and put in my evidence,

${ }^{10}$ The writer is quite aware that there are different views as to the scope of this test, varying, it seems, on one's regard for trial by jury. See the majority and minority opinions in Galloway v. United States, 319 U.S. 372 (1943), and criticism by Prof. McBaine, Trial Practice, 31 CAIIF. L. REv. 454 (1943). For present purposes it is not necessary to determine the point, for, whatever its scope, the test is plainly distinguishable from a "weighing" test.

4I FED R. Crv. P. 1, provides three tests: "They [the rules] shall be construed to secure the just, speedy and inexpensive determination of every action."

12 United States v. United States Gypsum Co., 67 F. Supp. 397, 418 (1946).

${ }^{43} I d$. at 418 . 
since I have not been required to rest. Then, at the conclusion, I can again have the evidence 'weighed.' Clearly there is every thing to gain, and nothing to lose."

One hesitates to raise the question, for someone may think it a fine idea, but why should we not adopt a mid-way "weighing" procedure in jury cases? The jury, too, is a trier of facts, and if it could be persuaded to "conclude," after hearing only the plaintiff's evidence, that he had failed to sustain the burden of proof, why bother the defendant with going on with his case? Why spend more of the taxpayer's money, when-if the argument is sound-it cannot be supposed that plaintiff would be helped by defendant's evidence, or that a juror, any more than a judge, could ever see the case in better perspective on hearing both sides?

The answer, probably, lies in a deep-seated feeling as to what is fair. Of course, defendant may not be required to put on his evidence, but since he ordinarily will have evidence which may throw light on the points at issue, the jury has always been expected to refrain from concluding anything until his case is in. Why, then, should a judge, as a trier of fact, be encouraged to act with any less impartiality-unless, indeed, the need to hurry and clear his docket is of paramount importance?

The Court of Appeal in Alexander v. Rayson ${ }^{44}$ was quite clear how the question should be answered: "Certainly no one would ever dream of asking a jury at the end of plaintiff's case to say what verdict they would be prepared to give if the defendant called no evidence, and we fail to see why a judge should be asked such a question in cases where he and not a jury is the judge that has to determine the facts." 45

The trial judge there had been asked, not to "weigh" the evidence, but merely to rule that, "accepting the evidence given on the defendant's behalf, there was no case to answer in law." ${ }^{\prime 46}$ It was decided that the trial court had discretion to grant such a motion, without requiring the moving party to rest. But the court said this was not only an irregular but a most inconvenient procedure: "For the judge in such cases is also the judge of fact, and we cannot think it right that the judge of fact should be asked to express any opinion upon the evidence until the evidence is completed." 47

\section{"Weighing" PlaintrfF's Evmence}

It has always been very mysterious to me how a judge goes about "weighing" a plaintiff's evidence. What does he weigh it against? Perhaps one's thinking is shaped by the picture of a scales of justice, with plaintiff's evidence on one side,

44 [1936] 1 K.B. 169.

45 Id. at 178 .

${ }^{46} \mathrm{Id}$. at 178 . This motion, it will be noted, asks for a ruling according to the "substantial" evidence test. It was made to test defendant's proof on an affirmative defense. No English court appears yet to have had the temerity to "weigh" evidence midway in a trial.

${ }^{47} \mathrm{Id}$. at 178. 
and nothing much on the other, that is, unless the assertions of defense counsel and the court's own doubts are to be put there. Of course, where a defendant has rested his case, the court perforce must reach a decision. But two things are noteworthy then. In the first place a defendant will ordinarily not rest unless he is quite sure of his ground..$^{48}$ Thus, as a practical matter, a court will not often be asked to decide a close case at mid-point. In the second, the very failure of the defendant to call any evidence, when his version of the facts might be helpful to the court, is a tacit invitation to view the case in a light favorable to plaintiff. 49

So also, it is difficult to see how it is meaningful to speak of the burden of proof in these cases. Of course the onus is upon plaintiff to put in substantial evidence to support the necessary allegations of his complaint, ${ }^{50}$ but that is all; there is no question of burden of proof in any other sense, for surely even slight evidence preponderates over none at all. ${ }^{51}$ However, the courts which purport to "weigh" the plaintiff's evidence carry through, and insist that plaintiff must somehow sustain a burden of proof. Judge Hamilton, it will be recalled, said in the Bach case that unless the plaintiff had made out his case by "a preponderance of evidence"52 the motion to dismiss should be granted. He did not explain how the thing was to be done.

In United States v. Morgan, ${ }^{53}$ Judge Medina not only decided that he must weigh the plaintiff's evidence to determine whether the burden of proof had been met, but took the position that the evidence should be weighed as it was introduced:

Don't forget that the pieces of the mosaic are constantly forming. The talk about putting the mosaic together at the end of the case means putting true, accurate, factual pieces together after the controversy on the facts has been resolved as to each

48 If defendant has no case at all, and is merely bluffing, the action of a court in strictly "weighing" plaintiff's evidence becomes a travesty, except to someone immersed in the old view that a law-suit is a sort of game.

${ }^{49}$ Kirby v. Tallmadge, 160 U.S. 379 (1895). The defendants here, in an action to remove a cloud upon title, had rested without introducing any evidence, and, when the decree went against them, brought this appeal. In affirming the lower court, Mr. Justice Brown said: "As they had it in their power to explain the suspicious circumstances connected with the transaction, we regard their failure to do so as a proper subject of comment. 'All evidence,' said Lord Mansfield in Blatch v. Archer, Cowper 63, 65 (1774), is to be weighed according to the proof which it was in the power of one side to have produced and in the power of the other side to have contradicted." Id. at 383. See also, The Eastchester, 20 F.2d 357, 358 (1927).

${ }^{50}$ See, 9 Wigrore, Evmence § 2494 (3rd ed. 1940).

si In Quock Ting v. United States, 140 U.S. 417 (1890). Mr. Justice Field found "inherent improbability" in the testimony of petitioner (a Chinese boy held for deportation), so it could be disregarded, but he stated the general rule to be that "positive testimony as to a particular fact, uncontradicted by any one, should control the decision of the court. ..." Id. at 420.

${ }^{62}$ Bach v. Friden Calculating Mach. Co., 148 F.2d 407, 410 (6th Cir. 1945). See text accompanying note 22 supra.

B3 118 F. Supp. 621 (E.D.N.Y. 1953). The charge here was a conspiracy to fix non-competitive prices in the purchase and sale of securities. 
piece. So you must not think that I am going to wait until perhaps a year from now to decide out of a huge welter of proof what are the pieces to be put together, ... as to a substantial number if I find the little piece to be black instead of white, how is it going to fit in. ${ }^{54}$

As a matter of conspiracy law, of course, this was plain error. For, as Mr. Justice Van Devanter pointed out in United States v. Patten: 55 "It hardly needs statement that the character and effect of a conspiracy is not to be judged by dismembering it and viewing its separate parts, but only by looking at it as a whole." ${ }^{\prime 66}$ And while the Justice's statement was made with respect to the suffciency of a pleading, it would seem to apply, a fortiori, to a piecemeal disposition of plaintiff's evidence, whether disposed of for lack of "weight," or for a supposed lack of "credibility." As a matter of evidence, though, how could the trial court resolve "the controversy on the facts" before the other side had been heard, unless, indeed, he gave weight to the unsworn statements of defense counsel? ? $^{57}$

In the Gypsum case, ${ }^{58}$ Judge Stephens also held that the burden of proof was on the plaintiff. He then went on to elaborate certain "principles of proof," which he said applied, though they were all derived from cases where both sides had been fully heard. Thus the "equivocal" evidence test was taken from Pennsylvania R.R. Co. v. Chamberlain. ${ }^{60}$ The court, there, in determining whether to grant a motion for judgment notwithstanding the verdict, said this: We, therefore, have a case belonging to that class of cases where proven facts give equal support to each of two inconsistent inferences; in which event, neither of them being established, judgment, as a matter of law, must go against the party upon whom rests the necessity of sustaining one of these inferences as against the other, before he is entitled to recover. ${ }^{61}$

Such a rule is perhaps too hypothetical to be of much use, even at the end of a trial, except as a mischief maker ${ }^{62}$ But, however that may be, there would seem to be no proper basis for using it in the middle of a non-jury case, especially where the case is a close one. That is pre-eminently not a time when the trial judge should "conclude" anything, one way or the other. For it may be

${ }^{54}$ Id. at Record, pp. 8518-19. See Steffen, The Invesiment Bankers' Case: Some Observations, 64 YATE L.J. 169 (1954); Whitney, The Investment Bankers' Case-Inchuding a Reply to Professor Steffen, 64 Yale L.J. 319 (1955).

s5 226 U.S. 525 (1913).

${ }^{56}$ Id. at 544 .

${ }^{57}$ The defendants were permitted to take more than three months in their opening statements, at the start of the case, to comment at length upon the government's exhibits, the "true" nature of the business, and so on and on. It is not humanly possible that some of these arguments did not get put in the scales to be "weighed" against the plaintiff's proof.

${ }^{58}$ United States v. United States Gypsum Co., 67 F. Supp. 397 (D.D.C. 1946).
${ }^{59} \mathrm{Id}$. at 449 .
${ }^{60} 288$ U.S. 333 (1933).
61 Id. at 339.

62 See Comments of Mr. Justice Black, dissenting in Galloway v. United States, 319 U.S. 372,405 (1943). Whether two possible inferences are so evenly balanced as to be precisely equal is surely a matter for the jury to determine. 
assumed, if the defendant were to put on his evidence, the matter would quickly be got off dead center, perhaps in defendant's favor, but by no means necessarily so. The fair thing, therefore, would seem to be to put the defendant to his proof, that is, unless he would prefer to rest his case.

The court's use of the "equivocal" evidence test in the Gypsum case ${ }^{63}$ will illustrate the point. The charge there, in general terms, was that defendant manufacturers had conspired to organize their industry and stabilize prices by the use of common patent license agreements. Certain exhibits, taken from the files of National Gypsum, were introduced as tending to show the alleged plan, and that company's connection with it. But, as to these, Judge Stephens said: The recital in the minutes of the May 14, 1929, directors' meeting of National of the chairman's statement that he had been "informed that all other manufacturers of gypsum products . . . except . . . American had agreed to sign a license contract . . .," and the resolution authorizing execution of license agreement with USG in the form submitted ... are equivocal. It is without dispute that the various companies were at this time considering the May 1929 licenses. It is no more inferable from these minutes that the various (prospective) licensees had agreed with each other to sign the license contract with USG than it is that they had agreed severally with USG to do so. ${ }^{64}$

This example alone should show that a "weighing" procedure is itself quite artificial, when only one side has been heard. Indeed, it is hard to imagine any fact from which conflicting inferences may not be drawn. If the trial court is unable to imagine any, defense counsel are only too ready to supply some plausible ones. ${ }^{65}$ To illustrate, the evidence in the Gypsum case showed that all but one of defendant manufacturers had met together in Chicago when the last license agreements were signed and, more important, that USG had issued its first general price bulletin at that time. One robust inference from this was that defendants had thereupon reached a common agreement to organize their industry and stabilize prices, but the court pointed out-at the suggestion of defense counsel-that since there was a "most favored nation" clause in the agreements, another inference was that they may merely have met together to see that one licensee was not getting better terms than another. Whatever one may think of this, it could - and did ${ }^{65}$ - serve in the "weighing" process to show that plaintiff had not sustained the "burden of proof."

63 United States v. United States Gypsum Co., 67 F. Supp. 397 (D.D.C. 1946).

"Id. at 508-9. (Emphasis added.)

${ }^{65}$ One hilarious example from the antitrust field! When erstwhile competitors are shown to have been putting in identical bids, it is a fair inference that some sort of connivance has been going on. But no, say defense counsel, since the bids are all exactly the same it really shows that there was "perfect competition," and hence the case should be dismissed. And, strangely, some courts have bought the argument. It would be more consistent with time-honored principles of fair trial, in such case, to ask the defendants to put in just a little evidence, under oath, to support their suggestion. Otherwise, trial upon the facts becomes nothing but trial by conjecture.

${ }^{66}$ United States v. United States Gypsum Co., supra note 63 at 509. 
Again, a subsidiary point in the Gypsum case was that the defendants had conspired to eliminate jobbers in the distribution of gypsum board. There was quite substantial evidence on the point, for USG had issued a price bulletin specifying that thenceforth the price to jobbers was to be the same as that to dealers. Moreover, among the subsequent exhibits was one in which a manufacturer had wired that "Lee Story must be eliminated immediately as a jobber." That would seem to make a prima facie showing, but the sender, an adverse witness, testified on cross examination that his wire was not meant that way. What he had wanted to say was that the manufacturer selling to Lee Story should cease giving him "a jobber's discount," if that were the case, not that Lee Story should be "eliminated." planation is consistent with his testimony that there was no elimination of jobbers but merely an elimination of their discount...." ${ }^{69}$ Thus, once more, the plaintiff had failed to sustain the burden of proof.

These illustrations may well appear unbelievable. But, in fact, they show what can happen, and with an able court, when a trial judge lays aside his judicial robes, midway through a trial, and undertakes to weigh plaintiff's evidence against what he imagines the defendant might prove. When the Gypsum case finally reached the Supreme Court, counsel for USG had a difficult time defending the trial court's findings. When he seriously urged that there was no sufficient showing that jobbers had been eliminated from the industry, Chief Justice Vinson leaned from the bench and said: "You mean, sir, that if the jobbers wanted to, they were free to continue in business without a profit." And that ended that.

The Supreme Court was also asked to decide whether, on motion to dismiss pursuant to Rule 41(b), the trial court had properly ruled that it must weigh the plaintiff's evidence and, further, whether the government must establish its case by a preponderance of evidence. But Mr. Justice Reed found it unnecessary to do so: "We do not stop to consider those rulings. They are not of importance in this case as we think the clear preponderance of evidence at the conclusion of the government's case indicated a violation of the Sherman Act."70

\section{On CredibIIITy}

It may be that a trial judge engages in a "weighing" process of a different order, though I doubt it, when he passes on the credibility of plaintiff's witnesses. Even so there is a question, not so much as to the weight to be given his conclusions, although that, too, is in issue, but as to how and when he should arrive at them. That is, should credibility be passed on at once-with all the certitude of a woman's intuition - or should a court wait as impartially as may

${ }^{67}$ Id. at $493 . \quad{ }^{68}$ Ibid. $\quad{ }^{69}$ Ibid.

${ }^{70}$ United States v. United States Gypsum Co., 333 U.S. 364, 388 (1947). 
be for the evidence to unfold? If experience had shown that trial judges are quite infallible in such matters, the sooner they should "conclude" that a witness is trustworthy or not, the better. Much time could be saved that way.

In jury cases, of course, the trial court's part in determining credibility is quite limited. Most jurisdictions treat credibility, like fact, as wholly a matter for the jury to determine. ${ }^{71}$ But a considerable number give the court a screening power, comparable to that under the "substantial" evidence test. The formulations vary, but they come down to something like this: If the trial judge decides that no reasonable person could properly rely on a witness' testimony essential to plaintiff's case, he may direct a verdict. ${ }^{72}$ Needless to say, the power to direct a verdict, like the power to set aside a verdict, ${ }^{73}$ is one to be exercised fairly, with a decent regard for the role of the jury. Trial by jury was instituted, not because a jury is more experienced or intelligent than a trial judge, but, to put it bluntly, as a necessary safeguard against biased or harsh judicial action. ${ }^{74}$

But in the non-jury case the trial judge is himself the trier of fact. And, since he has the opportunity to see the witnesses and observe their "demeanor" on the stand, great weight has always been given to his conclusions on credibility. ${ }^{75}$

71 See cases cited: 9 Wigmore, Evmence $\$ 2494$ (3d ed., 1940); McBaine, Trial Practice, 31 CALIF. L. Rev. 454, 461 (1943).

72 For instance, in Gunning v. Cooley, 281 U.S. 90, 94 (1930), Mr. Justice Butler said: "Issues that depend on the credibility of witnesses, and the effect or weight of evidence are to be decided by the jury." But he first had said: "A mere scintilla of evidence is not enough to require the submission of an issue to the jury. The decisions establish a more reasonable rule "that in every case, before the evidence is left to the jury, there is a preliminary question for the judge, not whether there is literally no evidence, but whether there is any upon which a jury can properly proceed to find a verdict for the party producing it, upon whom the onus of proof is imposed." "

${ }^{73}$ It is usual to say that a verdict may be directed for a defendant when the trial court would be bound to set aside a verdict for plaintiff on the ground that it was contrary to the weight of the evidence. But, as Wigmore points out (9 WIGMORE, EvIDENCE $\$ 2494$ (3d ed. 1940)), this test is neither helpful nor strictly accurate. Moreover, it is wholly inapt if sought to be applied in ruling on a motion midway of a trial.

${ }^{74}$ See discussion of the reasons for the Seventh Amendment, Clark \& Stone, Review of Findings of Fact, 4 U. CHr. L. REv. 190 (1937).

${ }^{75}$ Lord Shaw's statement in Clarke v. Edinburgh Tramways Co. (1919) H.L. 35, 36, is often quoted: "When a judge hears and sees witnesses and makes a conclusion or inference with regard to what is the weight or balance of their evidence, that judgment is entitled to great respect, and that quite irrespective of whether the judge makes any observation with regard to credibility or not. I can of course quite understand a Court of Appeal that says that it will not interfere in a case in which the judge has announced as part of his judgment that he believes one set of witnesses, having seen and heard them, and does not believe another. But ... in the ordinary case things are much more evenly divided; witnesses without any conscious bias towards a conclusion may have in their demeanour, in their manner, in their hesitation, in the nuance of their expressions, in even the turn of the eyelid, left an impression upon the man who saw and heard them which can never be reproduced in the printed page." See also, Judge Frank's remarks in Broadcast Music, Inc. v. Havana Madrid Restaurạt Corp., 175 F.2d 77 (2d Cir. 1949). 
It would be nonsense, though, to suggest that trial judges are always right, ${ }^{76}$ or even always unbiased, in determining credibility. In the nature of things, with the stress of argument in the conduct of a trial, with rulings to make on all manner of points, with the court's own predilections about the nature of the case, any trial judge, sitting alone, is very prone to take sides. Probably a jury takes sides, too, though possibly for different reasons, but in its case every precaution is taken to make sure that it will withhold judgment until the case is finally submitted. Partly this is because a jury must reach a group decision, but it is also because it would be unfair to do otherwise.

To get to the question, then, how does a judge determine credibility? The demeanor of a witness, while of importance, is surely an overrated factor. ${ }^{77} \mathrm{~A}$ good witness may testify with poise and assurance to an untruth, or a half truth, particularly if he knows there are no writings to controvert him; ${ }^{78}$ a poor witness may fumble and equivocate in telling the absolute truth. This is all commonplace. Essentially, it would seem, the process of determining credibility is not much different from that of determining any other fact. That is, a witness' credibility is really determined very largely by weighing his testimony against other "facts" in the case: his own answers upon cross examination; the testimony of the witnesses for the other side; the writings which have been introduced as exhibits. Only rarely, if ever, may a court properly delve into its inner consciousness to test an uncontradicted witness' testimony by the socalled inherent probabilities. ${ }^{79}$

${ }^{76}$ The trial judge in Quercia v. United States, 289 U.S. 466 (1933) called the jury's attention to the fact that defendant had frequently wiped his hands during his testimony: "It is rather a curious thing, but that is almost always an indication of lying. Why it should be so we don't know, but that is the fact." This was held to be reversible error. It would have been equally so-though the fact might never have come to light-if the court had acted on that basis when sitting without a jury. This and the other cases cited by Chief Justice Hughes in the course of his opinion raise a perceptible doubt whether some appellate courts have not overdone their deference to the trial judges' findings.

${ }^{77}$ It ordinarily becomes critical only in the closely balanced case, after both sides have been heard. In Powell \& Wife v. Streatham Manor Nursing Home [1935] A.C. 243, 256, Lord Macmillan pointed out that the House of Lords must not hesitate to exercise its jurisdiction to reverse when the 'rial court has erred on a question of fact, but then said: "Where, however, as in the present instance, the question is one of credibility, where either story told in the witness-box may be true, where the probabilities and possibilities are evenly balanced and where the personal motives and interests of the parties cannot but affect their testimony, this House has always been reluctant to differ from the judge who has seen and heard the witnesses, unless it can be clearly shown that he has fallen into error." See also, Flower v. Ebbw Vale Steel Iron \& Coal Co. [1936] A.C. 206, where the appeal was allowed.

${ }^{78}$ Judge Hand's comments on this sort of thing in United States v. Corn Products Refining Co., 234 Fed. 964, 978 (S.D.N.Y. 1916) are in point: "The documents were never intended to meet the eyes of any one but the officers themselves, and were, as it were, cinematographic photographs of their purposes at the time they were written. They have, therefore, the highest validity as evidence of intention, and, although in many instances Bedford attempted to contradict them, his contradiction only served to affect the general credibility of his testimony."

${ }^{79}$ See, Broadcast Music v. Havana Madrid Restaurant Corp., 175 F.2d 77 (2d Cir. 1949), where the trial court's dismissal at the end of plaintiff's evidence was sustained. 
In the Gypsum case ${ }^{80}$ Judge Stephens found all the adverse witnesses called by the government to be quite credible, particularly in their answers upon cross examination. But as to this, Mr. Justice Reed said:

The government relied very largely on documentary exhibits and called as witnesses many of the authors of the documents.... On cross examination most of the witnesses denied that they had acted in concert in securing patent licenses or that they had agreed to do the things which in fact were done. Where such testimony is in conflict with contemporaneous documents, we can give it little weight, particularly when the crucial issues involve mixed questions of law and fact. Despite the opportunity of the trial court to appraise the credibility of the witnesses, we cannot, under the circumstances of this case, rule otherwise than that Finding 118 is clearly erroneous. ${ }^{81}$

In one view, the Supreme Court may be taken to have said that the Gypsum witnesses, on cross examination, lacked credibility. That, of course, would have cut the ground completely from under the trial court's elaborate analysis of the evidence. But perhaps Mr. Justice Reed meant that, granting the witnesses' credibility, their testimony did not square with the other, better established, evidence in the case. That is to say, it simply lacked weight. For present purposes it is not necessary to decide which. It is surely evident that in either view the trial court was engaged in substantially the same enterprise.

Ordinarily, by the time a plaintiff has rested, there can be little more than a testing for consistency; the court's finding, then, at best, is one of prima facie credibility. That is, "credibility," like any "fact," is but the end product of a process of testing, and entitled to weight only according to the extent and accuracy of the testing. To put the matter very plainly, the findings of a trial court upon "credibility," when made midway of a trial, are not entitled to the deference and respect traditionally accorded them when both sides have been heard. Judges are not clairvoyant. ${ }^{82}$

\section{SPEED AND HURRY}

It should be plain by now that the amended Rule 41 (b) was not designed to aid in getting at the truth of a controversy. If that were its purpose, the trial court would have been admonished not to take sides early in a case; in fact, not to "conclude" anything, either as to "fact" or "credibility"-except in the

${ }^{80}$ United States v. United States Gypsum Co., 67 F. Supp. 397 (D.D.C. 1946).

81 United States v. United States Gypsum Co., 333 U.S. 364, 395-6 (1947). Finding 118 was to this effect: "The evidence... fails to establish that defendants associated themselves in a plan to blanket the industry under patent licenses and stabilize prices, as charged by the government."

82 See BoIEnN, TrIax JUDGe 132 (1952): "I distrust my own surface reactions to a witness's demeanor. He is seldom at ease; an adaptable knave will often accommodate himself more readily to the rigid and unnatural climate of the courtroom than will an honest man. One judge's impression of an open countenance may be another's impression of a shifty look. The most depraved character I ever prosecuted had the beatific expression of a choirboy." 
most obvious cases-until the other side had been heard. Or, according to timehonored practice, until after plaintiff had put in his rebuttal, and defendant his evidence in rejoinder. But this was not done. The new procedure, it seems, must therefore be justified very largely, if at all, on the supposed need.for speed, and, I suppose, on a tender solicitude for the taxpayer's dollar.

The case of Global Commerce Corp. v. Clark-Babbit Industries, ${ }^{83}$ recently decided by Judge Hand, will illustrate the point. Here was a contract case which, in the last analysis, turned on conversations between the two parties. Plaintiff introduced the various letters and wires sent during the negotiations, from which it appeared that by September 16th a "fairly complete proposed agreement" ${ }^{\prime \prime}$ had been reached calling for shipment by defendant of 10,000 tons of copra C.I.F. Mexican West Coast at a price of \$110.25. Complications developed as to defendant's source of supply, as to the authority of defendant's representative Myers, as to what, if any, performance bond should be required. But, on September 25th, plaintiff wired saying offer "firmly accepted" and that a letter of credit would be opened without performance bond. Defendant's Vice-President Thomas, at this point, called plaintiff's representative Klein in Mexico, discussed the deal, and invited Klein to New York.

Klein was called as a witness, and after the exhibits had been received and he had testified to his conversations with Thomas, plaintiff rested. It would seem that plaintiff had made out a prima facie case. Judge Walsh, however, dismissed from the bench, saying that plaintiff had not sustained "the burden of proof." Perhaps he felt uneasy at holding defendant to a contract for so large an amount without a written commitment on defendant's part, but, since Mexican law was said to apply, ${ }^{85}$ no writing was necessary.

It seems, though, that Judge Walsh simply refused to accept Klein's version of his talks with Thomas: "Now his testimony again doesn't sound in the words of Thomas. He speaks in terms of legal conclusions, that Thomas promised to deliver the 10,000 tons of copra without further delay as previously negotiated, I think he said." "86 Judge Walsh did not find that Klein lacked credibility, though he had doubts. What he said was this: "I can even see how over ten years of thinking about a grievance that these conversations can almost fall into that shape without deliberate distortion." 87

Again, speaking of Klein's testimony, Judge Walsh said: "Now the fact is that that sounds perhaps like a cable or a business letter. It does not sound like

83255 F.2d 105 (2d Cir. 1958). The case was heard by Judge Walsh, without a jury.

84 "Now as I view the transaction, between September 13th and September 18th, Myers and Klein negotiated a fairly complete proposed agreement - I will talk about the copra firstcalling for delivery of 10,000 tons of copra against a letter of credit which in turn was to be against a 5 per cent performance bond." Opinion of Judge Walsh, unreported.

${ }^{85}$ Global Commerce Corp. v. Clark-Babbitt Industries, 239 F,2d 716, 719 (1956),

${ }^{86}$ Opinion of Judge Walsh, unreported,

87 Ibid. 
what Thomas said in a telephone conversation." ${ }^{88} \mathrm{It}$ is, of course, immaterial whether Klein gave a literal version of Thomas' words; it would be enough if he gave, as nearly as he could remember, their intent and meaning. But, the question is this, by what process-except that of sheer conjecture-could any trial court possibly know what would "sound in the words of Thomas," or "like what Thomas said," when Thomas had not been called as a witness?

There was, of course, much else in the case, but this was critical evidence, and with all respect the court's disposal of it illustrates the grave danger in a procedure which permits a trial court to "weigh" plaintiff's evidence, quite by itself, to determine whether he has sustained the "burden of proof." In the nature of things the trial judge must put his own doubts and conjectureswhich may or may not be well founded-into the balance against plaintiff's proof. ${ }^{89} \mathrm{And}$, to do that, comes perilously close to requiring plaintiff to establish his case according to the rule of the criminal law, that is, beyond a reasonable doubt. Surely the rule-makers did not intend-nor were they authorized to make-so basic a change.

Nor, in this case, can it be said that much time was actually saved, except that of the trial court. For, on appeal, the time of the circuit bench-Judges Hand, Clark and Dimmock-was required to study the briefs, hear argument, and write an opinion. It would have taken fewer judge-hours, certainly, and contributed much to the fairness of the procedure, if the trial court had put the defendant to his proof. Both Myers and Thomas were available as witnesses; they had acted for the defendant; and, in perhaps a day, could have set matters straight-one way or the other. ${ }^{90}$ But as to this Judge Hand said: "If the plaintiff had wished to secure any evidence from Thomas, Myers or any other of the defendant's employees, it should have called them to the stand, in which event it would not have been limited in its cross-examination-Rule 43(b)."

${ }^{88}$ Commenting on Klein's testimony concerning an earlier conversation, Judge Walsh said: "Now coming to his testimony as to this conversation, he testified that he told Thomas that 'We already sold the copra purchased in the call from Myers'. Now I don't believe he said that. I mean that sounds to me like the retrospective thoughts of a lawyer - I mean of Klein, whether he was a lawyer or not, or whether he is now or was at the time of his conversation, -I think he still shows the effect of his early training. . . ." Ibid.

${ }^{89}$ By way of further example: "I might say at the outset I don't understand Myer's activities. If he were a dishonest man I don't see what he had to gain by making proposals out of sheer dishonesty if he didn't have a supply of copra or steel and yet offered the deal. The only two other conclusions are either that he was insane or that he did have a supply which was exhausted while Thomas and Klein haggled over the details of the transaction." With all due respect, conjectures of this sort have no place in a trial upon the facts. There was nothing in the record to show that Myers was dishonest, or insane, or that he did other than to promote a more or less usual business deal for the sale of copra. If Judge Walsh entertained such doubts, though, it would seem imperative that he should call the other side and get the truth.

${ }^{90}$ The court in Alexander v. Rayson [1936] 1 K.B. 169, 178-9 points out the inconvenience of stopping the case: "The witnesses ... were presumably in Court and the expense of their attendance had already been incurred." See text accompanying note 45 supra.

${ }^{91}$ Global Commerce Corp. v. Clark-Babbitt Industries, 255 F.2d 105, 108 (1958). The same point was made by Judge Stephens in the Gypsun case, 67 F. Supp. 397,419 (D.D.C. 1946). 
Aside from being unrealistic, the suggestion is curiously inverted. The court does not say so, but the implication is plain that, since a plaintiff may call the defendant's witnesses and interrogate them as if upon cross-examination, it follows that he must do so-or be charged with the trial court's adverse conjectures. Surely, that is going too far in the name of hurry..$^{92}$ The purpose of Rule 43(b) was to give each party a fuller opportunity to bring out the facts of a controversy to the end that cases might be decided on their merits, and less as matter of chance. ${ }^{93}$ There was no thought, so far as I can discover, that the parties should become "obliged to fish in their enemies' water." matter, in fact, such a course would often be suicidal, particularly since the rule permits the adverse party also to put leading questions to the witness, and, if need be, to impeach him. ${ }^{95}$ It seems Rule 43(b), like the original Rule 41(b), was drafted with the thought that you would pay some regard to the practice of the last 150 years..$^{96}$

Whether Judge Hand approved of the new procedure is not clear; he simply said the third sentence of Rule 41(b) permitted the trial court to weigh plaintiff's evidence, without hearing the other side. ${ }^{97}$ However, he did refuse to fol-

${ }^{92}$ Nor is it apparent how any time is saved, for surely it takes about so long to produce a given quantity of evidence, whichever party calls the witness.

${ }^{93}$ See generally, Pike \& Willis, The New Federal Deposition-Disconery Procedure, 38 Contu. L. REv. 1179 (1938).

94 Judge Hand's expression, in a different situation: Schwartz v. United Merchants \& Manufacturers, Inc., 72 F.2d 256, 259 (2d Cir. 1934). (Emphasis added).

${ }^{95}$ FED. R. CTV. P. 43(b): "and the witness thus called may be contradicted and impeached by or on behalf of the adverse party also, and may be cross-examined by the adverse party. ..." See generally, Johnson v. Baltimore \& O.R.R., 208 F.2d 633 (3d Cir. 1953).

${ }^{96}$ Many cases hold that when a plaintiff has produced substantial evidence to support his charges, as plaintiff appears to have done in the Global Commerce case, a failure on the part of the defendant as part of his case to call witnesses available to him and who knew the facts, must weigh strongly against defendant. Mammoth Oil Co. v. United States, 275 U.S. 13, 52 (1927); Local 167 v. United States, 291 U.S. 293, 298 (1934); Interstate Circuit v. United States, 306 U.S. 208 (1939). In Local 167 Mr. Justice Butler said: "The government introduced substantial evidence which uncontradicted and unexplained tends to show that the conspiracy and appellants' participation continued until the filing of the amended complaint. They were present in court but failed to testify in their own defense. It justly may be inferred that they were unable to show that they had abandoned the conspiracy. . . . Under the circumstances of this case their silence rightly is to be deemed strong confirmation of the charges brought against them."

${ }^{97}$ Judge Hand apparently thought Klein's testimony lacked credibility, though he had not observed Klein's demeanor on the witness stand, and Judge Walsh, who had, did not say he lacked credibility. It was just surmised that Judge Walsh was trying to be considerate: "we are a little surprised at the moderation with which he expressed himself."

This compares with Judge Walsh's own polite conjectures as to Thomas' possible state of mind when talking with Klein: " $T$ think that Thomas wanted very sincerely to save Klein any embarrassment from the transaction, and I think further that he would have been glad to go ahead with Klein and Consumidores [Klein's buyer] if he could have gotten the supplies to do it." Surely, this is all pure guesswork, and should have no place whatever in a trial upon the facts. 
low Benton v. Blair ${ }^{98}$ The trial court there, sitting without a jury, had also dismissed at the end of plaintiff's case, saying: "I am simply unable to accept as true the plaintiff's version that on the first time he met the defendant Blair in a two-hour conversation they made a contract, an oral contract, of the terms and tenor that the plaintiff contends for. ..."99 On appeal, Judge Tuttle said the trial court was correct in its assertion that it must "weigh" plaintiff's evidence, but that "it was clearly error ... to reject the uncontradicted, unimpeached and not inherently impossible or suspicious testimony of Benton...."100 But it may be the New York bench thought Judge Tuttle had somehow lapsed into the old practice, for he ended by saying that plaintiff's testimony made out "a prima facie case as to the existence of a contract."

\section{SPEEDIER Summary Judgments}

One wonders from all this whether there has not been some waste of time in the summary judgment procedure. That is, if a trial court can "conclude," from a simple reading of plaintiff's affidavits, that a defendant may not be able to make out a defense-regardless of whether an issue of fact is presented-why should it not enter judgment for plaintiff at once? Surely it would be stultifying to the court, and a waste of the taxpayer's dollar, to have to go on with a trial when the court is not prepared to believe the defendant's evidence. Perhaps, here too, the courts have simply failed to note that the rule-permitting the other party to put in his proof-was probably developed to protect him in his rights to a jury trial.

Some credence is given this idea by the comments of Mr. Justice Jackson in Sartor v. Arkansas Natural Gas Corp. ${ }^{102}$ There the question at issue was whether the price of gas at the well head prior to 1930 "was above $3 \dot{\xi}$ per m.c.f.," whatever that means. The trial court had given summary judgment for the defendant, based upon his affidavits, but this was held to be error:

The Court of Appeals below heretofore has correctly noted that Rule $\mathbf{5 6}$ authorizes summary judgment only where the moving party is entitled to judgment as a matter of law, where it is quite clear what the truth is, that no genuine issue remains for trial, and that the purpose of the rule is not to cut litigants off from their right of trial by jury if they really have issues to try. ${ }^{103}$

Subsequent courts have followed the Sartor case, without regard to whether a jury trial was involved. ${ }^{104}$ And, of course, Rule 56 itself has no special exception for those actions "tried by the court without a jury," as Rule 41(b) now does. So, perhaps the rule-makers really overlooked a point. But, it is submitted, there is a more basic reason for denying summary judgment in these cases,

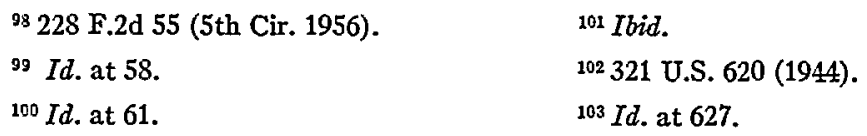

${ }^{104}$ See, Dewey v. Clark, 180 F.2d 766 (D.C. Cir. 1950). 
as, indeed, for denying a motion to dismiss where plaintiff has made out a prima facie case. That is, whether or not a jury is claimed, the very essence of a fair trial is that there shall be a full hearing on disputed questions of fact. ${ }^{105}$ Nor is this for the benefit of one adversary or the other; it rather is in the public interest, to the end that controversies may be fairly decided on their merits.

That "speed and hurry" are not reasons for limiting rights of this order has nowhere been better stated than by Judge Hand, dissenting in California Apparel Creators v. Wieder of California. ${ }^{106}$ Saying, first, that an action for unfair competition should be the last kind in which to invoke the remedy of summary judgment, he went on:

Indeed, when I see, as I am constantly seeing more and more, the increasing disposition to make use of that remedy, I cannot help wondering whether there is not danger that it may not rather impede, than advance, the administration of justice. It is an easy way for a court with crowded dockets to dispose of them, and the habit of recourse to it readily becomes a denial of that thorough, though dilatory, examination of the facts, on which justice depends even more than upon a studious examination of the law; for a mistake of law can always be reviewed. Speed and hurry ought to be the antipodes of judicial behavior. ${ }^{107}$

\section{SOME EQUTTY PRECEDENTS}

It is well now to re-examine the logic upon which the third sentence of Rule 41(b) was promoted. In essence it comes to this: Trial by jury is guaranteed by the Constitution (in actions at law in the federal courts), in particular by the Seventh Amendment, and hence it is for the jury, not the trial court, to determine questions of fact. And so, to quote Judge Stephens again, "if the reason for the jury trial practice does not exist in non-jury trials, where the judge is the trier of the facts, the jury trial practice ought not to be applied. ..."108 Thus it followed, in Judge Stephens' view, that a trial court sitting without a jury is bound to weigh a plaintiff's evidence, when ruling on a motion to dismiss, in order to dispose of his case at the earliest opportunity. ${ }^{109}$ This, surely, is logical nonsense. It assumes that the Seventh Amendment is the only reason for applying the prima facie test. ${ }^{110}$

If the assumption were correct the proponents of Rule 41(b), as amended,

${ }^{105}$ The case of Porter v. Wilson, 239 U.S. 170 (1915), is difficult to handle; it seems to confound so completely the notion of a full trial on the facts with the supposed differences between jury and non-jury trials.

${ }^{106} 162$ F.2d 893 (2d Cir. 1947).

${ }^{107}$ Id. at 903. See also, Arnstein v. Porter, 154 F.2d 464 (2d Cir. 1946).

${ }^{108}$ United States v. United States Gypsum Co., 67 F. Supp. 397, 417 (D.D.C. 1946).

${ }^{109} \mathrm{Id}$. at 420 .

${ }^{110}$ The English court, in Alexander v. Rayson, decided, quite as logically, that since a jury would not weigh evidence midway in a trial, a judge sitting without a jury should not either. See note 44 supra. 
should be able to point to some equity precedent in its support. For the Chancellor, at least, has known from the start that he-and not a jury -is "the trier of the facts." But, so far from finding support, it would appear there has been no practice whatever in equity to "weigh" evidence midway in a trial. In fact, it is black letter law that:

The case being set down for hearing on the bill, answer and proof, if defendant is willing to risk his case on plaintiff's proof, or rather the failure of plaintiff to prove his case, he should submit the case to the court for final hearing, and if he is not so satisfied, he should present what proof he desires or may be able to present.."

The reasons for this practice are instructive: the more so since the Federal Rules were drafted to afford a common procedure both for actions at law and suits in equity. ${ }^{112} \mathrm{In}$ part, it no doubt came about from the nature of the early equity proceeding, as one upon documentary evidence alone. ${ }^{113}$ That is, with both sides presented at the hearing there was little occasion for a defendant to move to dismiss. But, probably, a more significant reason lay in the scope of the appeal in equity, a matter to be discussed in detail in a moment. With a practice to examine the whole record on appeal-instead of passing only on assigned errors-and with full freedom to set aside the trial court's findings, ${ }^{114}$ there was good reason to have both sides fully heard, to the end that the suit might be disposed of once and for all by the appellate court.115

Perhaps the Illinois court, in Koebel v. Doyle, ${ }^{116}$ was making this point, when it said: "To permit such a motion [to dismiss at the end of complainant's case] would result in hearing a case by piece-meal, the sustaining of a motion resulting in an appeal and on reversal another hearing on more evidence, followed, perhaps, by another appeal."117 But, it may be Justice Cartwright merely thought

il 30 C.J.S. EQUITY $\$ 579$ (1942).

${ }^{112}$ Clark, Two Decades of the Federal Civil Rules, 58 CoLuss. L. REv. 435 (1958). 1929).

${ }_{113}$ See, Chancellor Bland's opinion in Winder v. Diffenderffer, 2 Bland 166, 184-94 (Md.

${ }^{114}$ See comment by Mr. Justice Jackson in District of Columbia v. Pace, 320 U.S. 698, 701-702 (1944).

115 The point was made by Etheridge, J., in Carter v. Studard, 118 Miss. 345, 352, 79 So. 225, 226 (1918), a case where the Chancellor had granted a motion for non-suit: "We have heretofore condemned the practice ... to sustain a motion at the conclusion of the complainant's evidence to strike out the evidence and give judgment for the defendant, without having the evidence of the defendant before the chancellor, and without requiring a defendant to elect to rest his case upon complainant's evidence. This practice is wholly unknown in chancery practice and procedure, and should not be indulged in the chancery court, as it undoubtedly protracts litigation. If the entire evidence was in the record, we could frequently enter final judgment here for one or the other of the parties, and this ought to be done whenever it is practical, to the end that law suits should have an end."

${ }^{116} 256$ IIl. 610,100 N.E. 154 (1912).

${ }^{117} I d$. at 614,100 N.E. at 156 . There is much in the court's language- this "cause was on hearing before the chancellor for a final decision on the merits"-to suggest that the thrust of the argument was against twice weighing evidence. If so, the equity objection to such motions is really an objection to the amended Rule $41(\mathrm{~b})$. 
it more expeditious to require the defendant either to rest or go on with his case. ${ }^{118}$

If the latter was his point, it was a dubious one, for surely some means should be provided, even in equity, to discontinue a proceeding where-in the opinion of the Chancellor - no person could reasonably say that the complainant had made out a case. In modern equity practice, ${ }^{119}$ much of the proof is presented by witnesses in court-just as in a law action - and it is therefore difficult to see why the same motion procedure should not be used in each case. ${ }^{120} \mathrm{At}$ all events, by the time Rule $41(\mathrm{~b})$ was drafted, many states had reached this position, ${ }^{121}$ and others-including Illinois ${ }^{122}$ - changed their practice shortly afterward. ${ }^{123}$

Thus, there is nothing in chancery practice to support the point that a trial judge, sitting without a jury, must "weigh" evidence when ruling on a motion to dismiss. Indeed, one senses that-all else aside - the early Chancellor, presiding as he did over a court of conscience, had certain scruples at engaging in such an enterprise, when the other side had not been heard, or had not closed its case. ${ }^{124}$ But a motion to test whether a complainant has introduced "substantial evidence" to support the necessary allegations of his bill is something else again. That far the draftsmen of Rule 41(b) were entitled to go, and that far only, without doing violence to the spirit of the prior equity practice.

Some states, it is true, have now gone even further. In its 1955 Civil Practice

${ }_{18}$ Many defendants nevertheless persisted in moving to dismiss, or to make some other motion, as to strike evidence. If the Chancellor's action in dismissing the bill was sustained on appeal, there was no harm done. Otherwise, the apparent harshness to a defendant with a good defense was sometimes softened by remanding the case with instructions to take further testimony. See Sundlun v. Volpe, 62 R.I. 55, 2 A.2d 875 (1938), and cases discussed.

${ }^{119}$ Equity R. 46, 226 U.S. 657 (1912), which require chancery courts to receive testimony in open court, was announced in 1912. See generally, Clark \& Stone, Review of Findings of Fact (1937) 4 U. CHI. L. REv. 190, 203-04.

${ }^{120} \mathrm{In}$ fact, even as early as 1885 , a lower Illinois court had approved a motion to strike plaintiff's evidence: "It is well settled in suits at law that a motion to strike out all the plaintiff's evidence is in the nature of demurrer to the evidence, and like such demurrer admits not only all the facts proved but also every conclusion which the jury might fairly and reasonably have drawn therefrom. We see no reason why the same rule should not apply to a suit in chancery, especially one like this, where the witnesses are all examined in open court...." Heiderich v. Heiderich, 18 Ill. App. 142, 143 (1885).

121 The Federal court in Cook v. Klonos, 164 Fed. 529, 535 (9th Cir. 1908), took a similar position: "In an action at law ... defendant, for the purpose of the motion, admits . . . facts which may naturally and rationally be inferred from the facts proven. There is no reason why the rule should not be applicable to a like motion to dismiss in an action of an equitable nature."

${ }^{122}$ See Johnson v. Johnson, 313 Ill. App. 193, 39 N.E.2d 389 (1942). The amended Rule 64, sub. 4, of the Civil Practice Act, made it clear that a defendant in equity, at the close of plaintiff's case, might "move for a finding in his favor" or "to dismiss the suit for want of equity," without being deemed to have rested. IrI. REv. STAT. Ch. 110, §188(4) (1949).

${ }^{123}$ See Phillips v. Phillips, 215 Md. 28, 135 A.2d 849 (1957), and cases cited.

121 A chancery court traditionally was interested in the fairness of its determinations, not in speed and hurry. See remarks of Judge Smith quoted in text accompanying note 130 infra. 
Act, Illinois bluntly provides, though upon what course of reasoning does not appear, that a judge sitting without a jury, whether at law or in equity, "shall weigh the evidence"125 when ruling upon a motion to dismiss at the close of plaintiff's case. Probably the rulemakers were caught in the spell of the arguments advanced for the amended Rule 41 (b). ${ }^{326}$ But they went the Federal rulemakers one better, for the trial court was not given an option, either to dismiss or to defer ruling until the other side had been heard. He "shall weigh the evidence."127

Arkansas, which has also changed its chancery practice, now allows a defendant-without being required to rest-to file a motion, at the close of the plaintiff's case, challenging the sufficiency of the evidence to warrant the relief prayed. Nothing was said, though, as to how the Chancellor should evaluate the plaintiff's evidence. But in Werbe v. Holt, ${ }^{128}$ where that was a point in issue, ${ }^{129}$ Judge George Rose Smith refused to approve a weighing procedure:

The American courts have always followed the theory of an adversary trial. In such a trial the parties are placed on equal terms and each develops his own proof by his own witnesses, though of course the party having the burden of proof must establish a prima facie case before his opponent need go forward with the evidence. The minority conception of a demurrer to the evidence is contrary to the traditional procedure in adversary trials, since the defendant is given an advantage. He has the opportunity of twice submitting the case to the trier of facts. . . Furthermore, in many instances the plaintiff's prima facie case must necessarily be somewhat weak, for the reason that only the defendant himself may be able to supply details needed to complete the picture. If the case goes to the trier of the facts on the plaintiff's proof alone, the defendant has the advantage of not exposing weaknesses in his own armor unless called to the witness stand by his adversary. For these reasons we have no hesitancy in adopting the majority rule as to the function of a demurrer to the evidence..$^{130}$

${ }^{25}$ Rule 64 (5), Civil Practice Act.

${ }^{202}$ In Phillips v. Phillips, 215 Md. 28, 135 A.2d 849, concurring opinion at 136 A.2d 862 (1957), Chief Judge Brune, likewise, urged the rulemakers to adopt the new Federal procedure to give the Chancellor power to "weigh" the plaintiff's evidence midway in a trial. But the reason he urged for the change was rather an argument for adopting the "substantial evidence" test: "The argument that because a court of equity is a court of conscience, the Chancellor should hear both sides before deciding the case is of little force or applicability in a situation of this sort, as I see the matter. It would, I think, be a strange manifestation of conscience to require a defendant to meet and disprove a case which the Chancellor, after a full hearing of the plaintiff's side of the matter, considered to be groundless or ill founded." (Emphasis added.)

${ }^{127}$ Supra note 125.

${ }^{128} 217$ Ark. 198, 229 S.W.2d 225 (1950).

${ }^{129} I d$. at 200,229 S.W.2d at 226 . The court stated the precise issue: "In the case at bar this question is of primary importance, for the appellant's proof was undoubtedly sufficient to raise a jury question had the case been tried in a circuit court. But if the problem is where the preponderance lay, a much closer question is presented."

${ }^{130} I d$. at 202-03, $229 \mathrm{~S}$.W.2d at 227. Perhaps Judge Smith was influenced by the fact that defendant's motion was in the nature of a demurrer. But, whether so or not, his comment would apply equally to a motion to dismiss, which traditionally was treated much like a demurrer. See note 2 supra. 


\section{The JURY's MANTLE}

It was much controverted, when the Federal Rules were drafted, whether the law or the chancery practice should apply on appeal. ${ }^{131}$ One thing was agreed, the procedure should be the same in each case, if that were at all possible. After full debate the chancery practice was adopted..$^{132}$ Not that there should be a complete trial de novo, ${ }^{133}$ as in early chancery practice, but definitely to adopt the modern equity procedure, under which the reviewing court is free to examine the complete record on appeal and-more important for present purposes-to reverse if, in its opinion, the trial court made an unwise, i.e. wrong, decision, either on the law or on the facts. ${ }^{134}$

The language adopting this position is found in Rule 52(a), which applies to "all actions tried upon the facts without a jury. . . ."135 After providing that the trial court "shall find the facts specially ...," the rule goes on to admonish reviewing courts that: "Findings of fact shall not be set aside unless clearly erroneous, and due regard shall be given to the opportunity of the trial court to judge of the credibility of the witnesses." 136 Why the rule was not phrased in the affirmative, that is, that a reviewing court shall set aside findings which are clearly erroneous, does not appear, but probably the actual meaning would be the same if it were stated that way. The reviewing court, thus, is given full power-indeed, is bound ${ }^{137}$ - to over-turn findings of fact which are, in its opinion, "clearly erroneous."

${ }^{131}$ See, Clark \& Stone, Review of Findings of Fact, 4 U. CHI. L. REv. 190 (1937).

132 MOORE, Federal Rules 246 (1956).

${ }^{133}$ See, United States v. du Pont \& Co., 351 U.S. 377, 381 (1956), where Mr. Justice Reed said: "We do not try the facts of cases de novo.",

${ }^{134}$ The Supreme Court has made it clear in many cases that it will not ordinarily engage in an extended review of the record. United States v. Yellow Cab Co., 338 U.S. 338 (1949); United States v. Timken Roller Bearing Co., 341 U.S. 593 (1951). But this cannot be other than a self-imposed restriction, perhaps dictated by the pressure of Supreme Court business, - Court of Appeals business is something else again-for there is nothing in Rule 52(a) or the prior equity practice to require it. Besides, it has no bearing on how the court should review such part of the record as it does examine.

The so-called Big case presents special problems, but, even so, it should not dictate general procedure. See McAllister, The Big Case, 64 HARv. L. Rev. 27 (1950); Seminar on Protracted Cases, 21 F.R.D. 401 (1957). See also Gottesman v. General Motors Corp., 268 F.2d 194 (1959), construing the Interlocutory Appeals Statute (28 U.S.C.A. \$1292(b)).

${ }^{135}$ Fed. R. Civ. P. 52(a).

${ }^{136}$ Ibid. (Emphasis added.)

${ }^{137}$ Lord Macmillan stated the English practice as follows: "If the judgment given in plaintiff's favour in the Court of first instance had been based on the verdict of a jury your Lordships' task would have been relatively easy, for there was plainly ample evidence on which a reasonable jury could have found for the plaintiffs and the verdict must have stood. But the case was tried by a judge sitting alone, and on appeal from the decision of a judge the Court of Appeal and this Court have a duty to exercise their jurisdiction as tribunals of appeal on fact as well as on law, a jurisdiction which your Lordships have never hesitated to exercise when satisfied that the Courts below have erred on a question of fact." Powell and Wife v. Streatham Manor Nursing Home [1935] A.C. 243, 256. See also, the court's comment in Montgomerie \& Co. v. Wallace-James, [1904] A.C. 73, 75. 
In concept, Rule 52(a) represented a sharp departure from the prevailing appellate procedure on the law side. There, for many years-without warrant of any Constitutional mandate- the mantle of the jury had been put upon the not unwilling shoulders of the trial judge. That is, the findings of the trial judge, as a "trier of the facts," were given the same finality as the verdict of a jury, ${ }^{138}$ and could not be set aside except where an appellate court could find no "substantial evidence" in their support. It was irrelevant that, in the opinion of the appellate court, the facts warranted an opposite result. The new rule, though, lodges authority with the appellate court; its opinion, and not that of the trial court, is to prevail, except only insofar as a "due regard" for the opportunity of the trial court to judge of "credibility," and a proper respect for the trial court's opinion, should stay its hand.

Notwithstanding the rule-maker's purpose, the words, "clearly erroneous," have had a curiously inhibiting effect. ${ }^{139}$ They seem to say, to the uninitiated at least, that appellate court powers have been limited, not extended; the trial court may no longer be reversed on the facts, it seems, except its findings are clearly erroneous. And so, some courts are back to the old "substantial evidence" test; if anything, more rigorously applied than ever. For how in common sense, it is asked, may the trial court's findings be clearly wrong, if there is to be found some fact, or some inference therefrom, which tends to support them?

To illustrate, the Seventh Circuit, in Penn-Texas Corp. v. Morse, ${ }^{140}$ recently reiterated its settled position that Rule 52(a) when read with 41(b) adopts the "substantial evidence" test. Here was an equity case brought to enjoin the issuance of roughly 169,500 shares of stock. The trial court dismissed at the close of plaintiff's evidence and, on appeal, Judge Finnegan sustained its action, pointing out that the trial court "had the primary function of finding the facts and choosing from among conflicting factual inferences those which he considered most reasonable."141

That much, of course, is true, but the court then went on to say:

Under such circumstances our power is limited to a determination of whether those inferences and conclusions have any substantial basis in the evidence. If such a basis is present the process of judicial review is at an end ... and the finding of the District Court must be accepted by this court.... And even where there is no dispute about the facts, if different reasonable inferences may fairly be drawn from the evidence, we

138 "Where a case is tried by the court, a jury having been waived, its findings upon questions of fact are conclusive in the courts of review, it matters not how convincing the argument that upon the evidence the findings should have been different." Per Shiras, J., in Dooley v. Pease, 180 U.S. 126, 131 (1900). See also United States v. Jefferson Electric Co., 291 U.S. 386, 407 (1934).

${ }^{139}$ For an extremely lucid explanation of the difference between the two tests, see Stern, Review of Findings, 58 HARV. I. REv. 70, 80-81 (1944).

${ }^{140} 242$ F.2d 243 (7th Cir. 1957).

${ }^{141} I d$. at 247 . 
are forbidden to disturb the findings based on such inferences unless they are clearly erroneous. ${ }^{142}$

Of course this shows a profound disregard of the background and purpose of Rule 52(a). ${ }^{143}$ Whether there is substantial evidence to support the trial court is beside the point. Moreover, this was made quite clear in the Gypsum case, ${ }^{144}$ when Mr. Justice Reed said:

The practice in equity prior to the present Rules of Civil Procedure was that the findings of the trial court, when dependent upon oral testimony where the candor and credibility of the witnesses would best be judged, had great weight with the appellate court. The findings were never conclusive however. A finding is "clearly erroneous" when although there is evidence to support it, the reviewing court on the entire evidence is left with the definite and firm conviction that a mistake has been committed. ${ }^{45}$

Rule 52(a) was drafted with no thought that it would apply to the findings of a trial court made upon purportedly "weighing" evidence midway in a trial. It stated a chancery practice, and there had been no practice of that sort in chancery. Moreover, since the rule was designed to deny to a trial court's findings the degree of finality which has always been accorded to a jury's verdict after both sides have been heard, it would seem, a fortiori, that findings made midway in a trial should have no greater sanctity. Or, to state the point another way, even though a trial court when sitting without a jury is "a trier of the facts," it is not privileged then, or at any stage of the case, to wear the jury's mantle.

\section{Deference to Appellate Courts}

One wonders just how the proponents of amended Rule 41 (b) expected to square it with Rule 52(a). Suppose a trial court does "weigh" evidence midway in a trial, and make findings of fact, what does that accomplish? Very little, indeed, except to cause delay and expense, if such findings may be set aside as "clearly erroneous," even though supported by "substantial evidence." That is, this is true, unless Rule 41 (b) is to be construed as having amended Rule 52(a) to read to this effect: "Findings of fact shall not be set aside unless clearly erroneous, and where a trial court has purported to weigh evidence at the close of

$142 I d$. at 247. This language was taken from Judge Kerner's opinion in Gaytime Frock Co. v. Liberty Mut. Ins. Co., 148 F.2d 694, 696 (1945). Judge Kerner, in turn, took it, in the main, from the opinion of Mr. Justice Murphy in Commissioner v. Scottish American Investment Co., 323 U.S. 119, 123-124 (1944). But that case had to do with an appeal from the Tax Court. And, what the Seventh Circuit failed to note, is that Congress provided specially many years ago that findings of the Tax Court-presumably because of its expertness in the fieldmay not be overturned when supported by "substantial evidence." There is no statute giving a similar measure of finality to findings of a trial judge in civil cases generally.

${ }^{143}$ For a good discussion, see IISEN \& Hone, Federal Appellate Practice, in FED. RuLes of CrvIL Procedure, 359, 418 et seq. (Rev. ed. 1947).

144333 U.S. 364 (1948).

145 Id. at 395. (Emphasis added.) 
plaintifl's case, they may not be set aside at all, if there is any substantial evidence in their support...." But Rule 52(a) was not amended in that way, and the incongruity of making such an exception in favor of mid-trial findings should at least give a court pause before improvising such an amendment.

More likely the proponents were trading on a certain lack of understanding -plus a little inertia - on the part of the appellate courts. Perhaps the rulemakers numbered some who were still not persuaded to the wisdom of extending appellate review, as is provided by Rule 52(a). If so, here was a way to bring back the old limited review which had prevailed at law-and even to make it apply in equity cases-all under the guise of adopting a liberal rule to speed up trial. If such was their purpose, they succeeded better than they should have done. But why stop part way; if the trial court's findings at mid-trial are entitled to the finality of a jury's verdict, why not abandon entirely the notion of a full appeal as in chancery practice and give a similar finality to the court's findings at the end? That, too, would simplify the work of the appellate courts, and so promote an earlier disposition of cases.

It is not proposed to examine in more than brief detail the reasons for the "clearly erroneous" test stated in Rule 52(a). Basically, it rests on the principle that in our jurisprudence no litigant, who has more than a semblance of a case, is to be thrown out of court by the ipsi dixit of a single judge. Congress has made generous provision for a further hearing. Nor can it be said that an appellate bench is less competent than the trial court to pass on the law and the facts of a case. Indeed, it is usually more able to do so, for the appellate bench is relieved of the hurry of daily trial work; there is the benefit of consultation; and, more important, the case may be seen in fuller perspective than often is possible to a single trial judge. Only to the extent that the trial judge's findings depend on matters of credibility - after both sides have been heard-should a "due regard" for his opportunity to see and hear the witnesses restrict review.

The verdict of a jury, on the other hand, is a very different thing. The essence of the right to trial by jury lies in the assurance that a litigant shall have the judgment of a panel of his peers upon disputed questions of fact. ${ }^{146}$ Likewise in the case of many administrative agencies, though for different but similar reasons, Congress has provided that findings may not be set aside, except where there is no "substantial evidence" in their support. ${ }^{147}$ In these areas it is not open to an appellate court to say that we view the facts differently. ${ }^{148}$ But a

${ }^{146}$ Galloway v. United States, 319 U.S. 372 (1943), "Since judicial review of findings of trial courts does not have the statutory or constitutional limitations on judicial review of findings by administrative agencies or by a jury, this Court may reverse findings of fact by a trial court where "clearly erroneous'." Per, Mr. Justice Reed in United States v. United States Gypsum Co., 333 U.S. 364, 395 (1948).

${ }^{147}$ See, NLRB v. Columbian Enameling \& Stamping Co., 306 U.S. 292, 300 (1939), for discussion of the similarities between the rule for juries and that for administrative agencies. See also Brown, Fact and Law in Judicial Review, 56 HARv. I. REv. 899 (1943).

${ }^{148}$ Stern, Review of Findings of Administrators, Judges and $J_{\text {uries, }} 58$ HARv. L. REv. 70, 73-78 (1944). 
single trial judge enjoys no unique status; he can point to no Constitutional provision to give special weight to his findings; he has no Congressional sanction giving finality to his actions. Nor is he appointed because of any special competence; his training and background are those of the appellate judge, no more and no less.

Thus, not only is the way open, but it would seem to be in the public interest to make sure that an appellate court does have freedom to review-and if need be to set aside ${ }^{149}$ - the determinations of a single trial judge. After all, the appellate court has a national (or state-wide) jurisdiction; it has the prime responsibility of making sure that the laws of the realm are enforced throughout its length and breadth, equally and fairly. That a given policy, judge-made or statutory, should result in one decision in one trial court and on much the same set of facts in an exactly opposite one in another, is surely not tolerable. Yet, under the old "substantial evidence" rule, ${ }^{150}$ if each trial court could point to some evidence which might impress a reasonable man-as each well might do in any close case-an appellate court could do very little to reconcile the two decisions. That surely tended to hodge podge, not justice according to law.

The "clearly erroneous" test, as pointed out above, was not adopted casually; it was carefully chosen to give the appellate courts power in law cases to take greater responsibility than theretofore. ${ }^{151}$ And so, by similar token, the amendment to Rule 41(b) can only be regarded as a step in the wrong direction. It operates to set the judgment of the trial court above that of the appellate court, whereas Rule 52(a) was designed to accomplish the exact opposite. When a trial judge passes on a motion to dismiss at the end of a plaintiff's case, therefore, a due deference to the appellate court ${ }^{122}$ should impel him to ask: Is this evidence, when viewed in a light most favorable to plaintiff, sufficient that an appellate court might reasonably decide in plaintiff's favor? If so, the motion should be denied.

This, of course, is essentially the test used in jury cases. It would serve the same basic purpose, that is, to insure that the appellate court, like the jury, should have the evidence upon which to reach its orem decisions. That the trial

${ }^{149} \mathrm{This}$, of course, was the practice in chancery, and some appellate courts recognize, to a degree, that they now have the same responsibility in hearing appeals at law, when the case is tried by a court without a jury. See Judge Frank's analysis in Orvis v. Higgins, 180 F.2d 537, 539 (2d Cir. 1950). Cf. comment by Clark, Special Problems in Drafting and Interpreting Procedural Codes and Rules, 3 VAND. L. Rev. 493, 506 (1950).

${ }^{150}$ The "substantial evidence" rule means different things at different times, but the test does not change. When used in passing on a motion to dismiss, it tends to put the defendant to his proof; when used after a verdict, it tends to give finality to the decision. What the proponents of amended Rule 41(b) seem to have wanted was to throw out the first application, but to appropriate the second. They were wrong on both counts.

${ }^{151}$ For the arguments, pro and con, see Clark \& Stone, Review of Findings of Fact, $4 \mathrm{U}$. CHI. L. REv. 190 (1937).

${ }^{152}$ Deference is a quality which should work both ways; it is not all owed to the trial court. Rule 41(b) gives the trial court this option. 
judge may have "concluded," after hearing only one side, that he would decide for the defendant, ${ }^{153}$ is interesting, but not too important. If he knows that there is substantial evidence in the record upon which an appellate court might well decide otherwise, it is a plain perversion of fair trial to purport to "weigh" the plaintiff's evidence, find it wanting, and then to grant defendant's motion to dismiss. In such case, as when trial is had before a jury, it is the first function of the trial judge to hear all of the facts, a difficult and most important task-but one "on which," we are assured, "justice depends even more than upon a studious examination of the law; for a mistake of law can always be reviewed."154

\section{FINALLY}

There is a certain rhy thm in legal matters, as in most social phenomena. Perhaps the day is not yet, but it does seem that the heresy set afoot by Hoyt, C. J., in 1896155 -that a trial court is to be encouraged to "weigh" evidence midway in a trial-should have about run its course. No single argument advanced for the proposal, it seems, will bear careful analysis. ${ }^{156}$ And, the unstated central idea, that the doubts and conjectures of a trial judge may properly be put in the balance and weighed against the plaintiff's facts, established by exhibits and sworn testimony, is completely foreign to our notions of fair trial.157

The obvious course is to delete the third sentence of Rule 41(b), at the earliest opportunity. ${ }^{158} \mathrm{~A}$ misbegotten offspring of an unseemly desire for speed and hurry, it has no place in our system of justice. It strikes at the citizen with a substantial case; the one who least of all should be summarily put out of court. There are many ways of expediting the trial of cases, ${ }^{159}$ without bartering away

${ }^{153}$ An $i m p u l s i v e$ judge, no less than a "timid" or a "biased judge"-if I may add a psychiatric category to Mr. Justice Frankfurter's dictum- "is intrinsically a lawless judge." Wilkerson v. MIcCarthy, 336 U.S. 53, 65 (1949).

${ }^{154}$ Supra note 107.

155 Ibid.

${ }^{156} \mathrm{Of}$ course, as Arnold has said, argumentative attack on such a device as Rule 41(b), related as it is to deeply rooted notions of limited review, may well be pointless; "if the emotional need for the institution is strong," argument "does not change the institution; instead it complicates its jurisprudence or its theology, until the attack is deflected and loses its force in a maze of learning." Arnold, A pologia for Jurisprudence, 44 YaIE L.J. 729, 748 (1935).

${ }^{157}$ Nor would it help matters to shift to a "probability" or "degree of belief" test. See, however, MIcBaine, Burden of Proof: Degrees of Belief, 32 CALIF. L. REv. 242 (1944). "Probability," or a "belief" founded on probabilities, has no place midway in a trial upon the focts, that is, however strange or improbable a plaintiff's case may seem to be, it also may be based on cold fact. Truth, it is said, is often stranger than fiction. It is no more respectable, therefore, to base a "belief" on conjectures as to what a defendant probably might prove, than it is to "weigh" such conjectures against plaintiff's evidence.

${ }^{158}$ It would be a wise course to replace the third sentence with the following: "In ruling upon the defendant's motion the court shall view the evidence and all inferences to be reasonably drawn therefrom in a light most favorable to the plaintiff." See text at note 12 supra.

${ }^{159}$ See particularly the recent study by ZeIsei, Kalven \& Buchrolz, DeLAY IN THE COURT (1959). 
the rights of litigants to have a full hearing of their controversy. And, incidentally, it is not for the courts-or the rulemakers-to engage in a bartering enterprise; Congress has control of the purse strings and, so far as I know, has never been niggardly when an issue of fair trial was before it.

It was not the purpose of this study to examine how the third sentence of Rule 52(a) has worked in practice. But it is apparent that it too has worked badly. It seems, therefore, that the rule-makers, when next they convene, should seriously consider making the rule say precisely what it was intended to mean. The following is suggested:

Findings of fact shall be set aside when clearly erroneous, and shall be regarded as being clearly erroneous, when, although there may be substantial evidence in their support, the reviewing court, on examining the entire evidence before it, and after giving due regard to the opportunity of the trial court to judge of the credibility of the witnesses, is left with the definite and firm conviction that a mistake has been committed. ${ }^{160}$

And so, it would seem the traditional mid-point test of whether a prima facie case has been made out, instead of being a "refinement of technicality," is a necessary safeguard of justice, as much in court cases, as in those tried before a jury.

${ }^{160}$ This definition of "clearly erroneous" is that stated by Mr. Justice Reed in United States v. Gypsum Co. 333 U.S. 364, 395 (1947); supra note 145. But, where the Justice says a finding may be set aside "although there is evidence to support it," the word "substantial" has been added. This makes the test explicit and, in the writer's view, does not change its meaning. Also the words "before it" have been added to the phrase on "the entire evidence." This, too, probably does not change the Court's meaning; at the same time it recognizes that the Court has a free hand to review all or only part of a record on appeal as justice may require, or as the Court's time will permit. 